\title{
Measurement of ectoenzyme activities as an indication of inorganic nutrient imbalance in microbial communities
}

\author{
M. M. Sala ${ }^{1, *}$, M. Karner ${ }^{2}$, L. Arin' ${ }^{1}$, C. Marrasé $^{1}$ \\ ${ }^{1}$ Institut de Ciències del Mar (CSIC), P. Joan de Borbó s/n, 08039 Barcelona, Spain \\ ${ }^{2}$ University of Hawaii, Department of Oceanography, 1000 Pope Road, Honolulu, Hawaii 96822, USA
}

\begin{abstract}
Assessment of nutrient limitation in microbial populations in marine environments is an important topic. Existing methodologies generally demand long incubations in an experimental assay manipulating nutrients. We suggest a novel approach using the ratio between 2 ectoenzymatic activities, alkaline phosphatase (APA) and aminopeptidase (AMA), to evaluate nutrient limitation of microbial communities in situ. APA is used as an indication of P limitation and AMA of N limitation. The ratio bypasses the use of biomass estimations to calculate specific activities, which are errorprone and time-consuming. Our results from enrichment experiments have shown that the ratio APA:AMA increases in P-deficient treatments, and decreases after inorganic P addition. After P-deficient nutrient addition (n treatments) the ratio APA:AMA increased to $90-230 \%$, whereas following $\mathrm{N}+\mathrm{P}$ balanced additions the ratio decreased to $30-70 \%$ of the initial value. These results demonstrate that this approach is easy, quick and gives a general insight into the nitrogen versus phosphorus nutrient balance of the communities without the need for biomass estimations or measurement of actual nutrient concentrations.
\end{abstract}

KEY WORDS: Alkaline phosphate $\cdot$ Aminopeptidase $\cdot \mathrm{N}: \mathrm{P}$ ratio $\cdot$ Microbial community

\section{INTRODUCTION}

Nutrient deficiency of microorganisms has been assessed in various environments, especially in aquatic ecosystems, where variations of phosphorus $(\mathrm{P})$ or nitrogen $(\mathrm{N})$ deficiency may be important in the growth and collapse of blooms (Healey \& Hendzel 1976). There is recent controversy about which is the nutrient commonly limiting primary production in the oceans (Downing 1997, Tyrrell \& Law 1997, Tyrrell 1999, Guildford \& Hecky 2000). However, in some localized areas, $\mathrm{P}$ has been identified as the limiting nutrient (Cotner et al. 1997, Wu et al. 2000), e.g. in the Mediterranean (Berland et al. 1980, Bonin et al. 1989, Krom et al. 1991, Thingstad et al. 1998, Zohary \&

*E-mail: msala@icm.csic.es
Robarts 1998). In spite of many attempts to find suitable indicators, there is no optimal approach for rapidly discerning between $\mathrm{N}$ and $\mathrm{P}$ nutrient limitation in natural planktonic communities.

A possible indirect way of rapidly evaluating nutrient deficiency of cells is by the determination of ectoenzyme activities. Nutrient limitation may induce cells to synthesize ectoenzymes to enable the acquisition of the limiting nutrient (Hoppe 1983). Ectoenzyme activities may thus serve as a proxy to nutrient limitation, not by indicating the amount of the proper substrate present, but by pointing towards the physiological state of the cell or of the total microbial population. Specifically, alkaline phosphatase activity (APA) has been used in many environments as an indicator of phosphorus deficiency (Pettersson 1980, Smith \& Kalff 1981, Gage \& Gorham 1985, Vrba et al. 1995, Rose \& Axler 1998). Aminopeptidases (AMA) hydro- 
lyze peptides and proteins, which comprise a major part (and probably the most utilizable fraction) of the marine organic N pool (Henrichs et al. 1984, Coffin 1989, Keil \& Kirchman 1991). Recently, Patel et al. (2000) have shown negative correlations between inorganic nitrogen concentrations and AMA activities. Leucine-methyl coumarinamide, an artificial fluorogenic substrate suitable for estimating aminopeptidase activities (Hoppe et al. 1988), may likewise serve as an indicator of $\mathrm{N}$ limitation. These enzymes, however, can be partially constitutive and should be corrected by the biomass of the producers. They can be synthesized by bacteria and by phytoplankton (Hoober \& Hughes 1992, Martinez \& Azam 1993, Berges \& Falkowski 1996). Therefore, accurate biomass estimations of all organisms producing 1 enzyme class to yield biomassspecific enzyme activities are further complicated. In order to bypass the use of biomass estimations, we suggest using the ratio between alkaline phosphatase and aminopeptidase activities (APA:AMA) as an indicator of $\mathrm{N}$ versus $\mathrm{P}$ limitation of the whole microbial community. We expect APA to be relatively more important than AMA in P-limiting conditions and the other way around when $\mathrm{N}$ is the limiting nutrient. Therefore, the APA:AMA ratio should be relatively high when P limitation prevails and relatively low when $\mathrm{N}$ limitation is more severe than $\mathrm{P}$ limitation. These changes in community enzyme activity could be due either to physiological adaption or to changes in species composition. This reasoning leads us to hypothesize that nutrient additions with different N:P ratios should result in alterations of the APA:AMA relationship.

To test the validity of this approach, we carried out microcosm experiments to examine the response of natural plankton communities to different nutrient inputs.

\section{MATERIAL AND METHODS}

Description of the experiments. Long-term microcosm experiments: We performed 2 long-term microcosm experiments with water from the Catalan coast (Masnou, $20 \mathrm{~km}$ north of Barcelona) and from ca $1 \mathrm{~km}$ offshore. The first experiment (continuous-enrichment) was carried out in October 1997, and the second (single-pulse enrichment) in March 1998.

Surface water $(0.5 \mathrm{~m}$ depth) was collected in plastic (75 1) containers previously washed with a sodium hypochlorite solution. The water was taken to the laboratory in less than $1 \mathrm{~h}$ and prescreened with a Nylon mesh $(150 \mu \mathrm{m})$. Microcosms were constituted by six 151 cylindrical containers incubated at in situ temperature a $12 \mathrm{~h}$ light:12 h dark cycle. Light intensity was $250 \mu \mathrm{E} \mathrm{m}^{-2} \mathrm{~s}^{-1}$. Turbulence was generated in the microcosms by vertically oscillating plastic grids to avoid set- tling of organisms. This allowed us to generate turbulence at levels up to $0.055 \mathrm{~cm}^{-2} \mathrm{~s}^{-3}$, similar to strong wind events in coastal waters (Peters \& Redondo 1997). Duplicate treatments consisted of $\mathrm{N}$ and $\mathrm{N}+\mathrm{P}$ enrichment (n and $\mathrm{np}$ ), and a control (k) without additions. Sampling took place daily using a glass tube connected to a silicone tube. The first milliliters of each subsample were discarded.

Microcosms were incubated for $4 \mathrm{~d}$ in the continuous-enrichment and for $7 \mathrm{~d}$ in the single-pulse experiment. In the latter, after $7 \mathrm{~d}, \mathrm{P}$ was added to 1 of the replicates of Treatments $\mathrm{n}$ and $\mathrm{np}$, and the response of the community to the new nutrient conditions was monitored every $6 \mathrm{~h}$.

Short-term single-pulse experiments: Five short-term experiments (with 4 treatments) were run on 5 consecutive days in September 1994. Treatments in duplicates consisted of additions of $\mathrm{N}(\mathrm{n}), \mathrm{P}(\mathrm{p}), \mathrm{N}+\mathrm{P}(\mathrm{np})$, and a control $(\mathrm{k})$ without additions. Water was taken at $10 \mathrm{~m}$ depth at the 'Point B' sampling station, a few hundred meters off the coast at Villefranche-sur-Mer, France, Northwestern Mediterranean Sea. Samples were incubated for $1 \mathrm{~d}$ in $1 \mathrm{l}$ acid-washed bottles at seawater surface temperature (flow-through deck incubators) with natural light.

Nutrient additions: In the long-term continuousenrichment experiment, nutrients were added daily and consisted of $1 \mu \mathrm{M} \mathrm{NaNO} \mathrm{Nan}_{3}$ in $\mathrm{n}$ treatments (P-deficient), and $1 \mu \mathrm{M} \mathrm{NaNO}_{3}$ and $0.06 \mu \mathrm{M} \mathrm{Na}_{2} \mathrm{HPO}_{4}$ in $\mathrm{np}$ treatments (nutrient-balanced). To both $\mathrm{n}$ and $\mathrm{np}$ treatments, silicate $\left(2 \mu \mathrm{M} \mathrm{Na} \mathrm{SiO}_{3} \cdot \mathrm{H}_{2} \mathrm{O}\right)$ and a tracemetal mix (Guillard 1975) were also added. Controls (k) were left unamended.

In the long-term single-pulse experiment, nutrients were added in a single input before Time $0\left(t_{0}\right)$. Final concentrations of the pulse were $16 \mu \mathrm{M} \mathrm{NaNO}_{3}, 0.1 \mu \mathrm{M}$ phosphorus $\mathrm{Na}_{2} \mathrm{HPO}_{4}$ (n treatments), and $16 \mu \mathrm{M}$ $\mathrm{NaNO}_{3}, 1.0 \mu \mathrm{M} \mathrm{Na}_{2} \mathrm{HPO}_{4}$ in np treatments. The N:P ratios of the additions were 160 for $n$ and 16 for $n p$. Treatment np was therefore, nutrient balanced while Treatment $n$ was $P$ deficient. Silicate $\left(30 \mu \mathrm{M} \mathrm{Na}{ }_{2} \mathrm{SiO}_{3} \cdot \mathrm{H}_{2} \mathrm{O}\right.$ final concentration) and a trace-metal mix were added to both $\mathrm{n}$ and $\mathrm{np}$ treatments. After $7 \mathrm{~d}$, an additional $\mathrm{P}$ $(1 \mu \mathrm{M})$ pulse was added to one of the replicates (a) of Treatments $n$ and $n p$, while the $b$ replicates were unaltered. The experiment was then continued for $30 \mathrm{~h}$ with $6 \mathrm{~h}$ subsampling intervals for microbial parameters to evaluate the response of this second pulse.

Additions in the short-term enrichment experiment

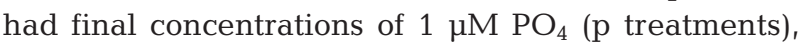
$5 \mu \mathrm{M} \mathrm{NO}_{3}+\mathrm{NH}_{4}$ equally distributed (n treatments), and both nutrient additions in the np treatments. Nutrients were added in a single-pulse at $t_{0}$.

Parameters measured. Chlorophyll a (chl a) was estimated fluorimetrically in the long-term experiments 
(Yentsch \& Menzel 1963). Between 15 and $20 \mathrm{ml}$ samples were filtered through Whatmann GF/F filters. The filters were ground in $90 \%$ acetone and left for at least $2 \mathrm{~h}$ in the dark at room temperature for chl a extraction. The fluorescence of the extract was measured with a Turner Designs fluorometer.

Inorganic nutrients $\left(\mathrm{PO}_{4}, \mathrm{NO}_{3}, \mathrm{NO}_{2}, \mathrm{NH}_{4}\right)$ were measured following the standard procedure described by Grasshoff et al. (1983). Total inorganic nitrogen (TIN) was calculated by adding the molarity of $\mathrm{NO}_{3}, \mathrm{NO}_{2}$, $\mathrm{NH}_{4}$. The N:P ratio is molar and is calculated by dividing TIN values by $\mathrm{PO}_{4}$ values.

Bacterial concentration in the long-term experiments was estimated by flow cytometry following a methodology described in Gasol \& del Giorgio (2000). Samples $(1.5 \mathrm{ml})$ were fixed with $0.15 \mathrm{ml}$ of a $10 \%$ paraformaldehyde and $0.5 \%$ glutaraldehyde mixture and stored at $-80^{\circ} \mathrm{C}$. At the time of determination, samples were thawed and run through a FACScalibur (Becton and Dickinson, San Jose, CA, USA) flow cytometer with laser emission of $488 \mathrm{~nm}$. Bacteria had previously been stained with SYTO13 (Molecular Probes Inc., Eugene, OR, USA) at $1.6 \mu \mathrm{M}$. Samples were run at low flow speed (about $12 \mu \mathrm{min}^{-1}$ ) and data acquisition was in log mode until about 10000 events were acquired. As an internal standard we added $10 \mu \mathrm{l}$ of a solution containing yellow-green $0.92 \mu \mathrm{m}$ latex beads (Polysciences Inc., Warrington, PA, USA) at a concentration of $10^{6}$ beads $\mathrm{ml}^{-1}$. Bacteria were detected by their signature in a plot of side-light scatter versus green fluorescence. In the short-term experiments, bacterial numbers were obtained by epifluorescence microscopy (Zeiss Axioplan, 100× objective) after $2 \%$ formaldehyde-fixing and DAPI staining of seawater filtrate on $0.2 \mu \mathrm{m}$ polycarbonate filters (Porter \& Feig 1980).

In the long-term experiments, as an estimation of bacterial activity we measured the rate of incorporation of tritiated leucine into protein following the method of Kirchman et al. (1985) with the Smith \& Azam (1992) modifications as described by Kirchman (1993). Tritiated leucine from Amersham (151 mCi $\mathrm{mmol}^{-1}$ ) was brought to a concentration of $1 \mu \mathrm{M}$ by mixing with non-radioactive leucine at 1:9 hot:cold, and dispensed (final conc. $40 \mathrm{nM}$ ) to $1.2 \mathrm{ml}$ of sample. This concentration was enough to saturate incorporation according to the curves obtained during the experiment. We used 3 replicates and 2 blanks killed with $50 \%$ TCA, and incubated them for between 1 and $2 \mathrm{~h}$ in the dark at $18^{\circ} \mathrm{C}$. The incubation was stopped with $50 \%$ TCA. Samples were rinsed twice by centrifugation in 5\% TCA and then counted in a Packard scintillation counter after addition of Optiphase Hisafe II scintillation cocktail.

For determination of the APA and AMA activities in the long-term experiments, we used fluorogenic sub- strates (Hoppe 1983, 1993) and followed a modification of the methodology described by Sala \& Güde (1996, 1998). The substrates 4-MUF-P-phosphate and leucine 7-amido-4 methylcoumarin were dissolved in a 1:10 methylcellosolve:sterile water solution, or in sterile water, respectively, to $2.4 \mathrm{mM}$. Substrates were added at saturating concentrations (200 $\mu \mathrm{M}$ final conc.) to $1 \mathrm{ml}$ subsamples in replicates. Fluorescence in the samples was measured immediately after addition of the substrate $\left(t_{0}\right)$, and after an incubation of $1 \mathrm{~h}\left(t_{1}\right)$. Incubation was in the dark at room temperature. Fluorescence was read on a Shimadzu spectrofluorometer RF-540 at $365 \mathrm{~nm}$ emission and $446 \mathrm{~nm}$ excitation wavelengths. Increase of fluorescence units during the incubation time was converted into activity by preparing a standard curve with the end product of the reaction, 4-methyllumbelliferone for APA, and 7-amino-4-methylcoumarin for aminopeptidase. In the short-term experiment, APA and AMA were measured following a similar procedure to that described above, but using final concentrations of $1.5,3,6,12,24$ and $48 \mu \mathrm{M}$ of the same substrates in $5 \mathrm{ml}$ samples, and calculating $V_{\max }$ using a non-linear model assuming Michaelis-Menten kinetics.

Specific activities were calculated by dividing ectoenzyme activities by the sums of bacterial and algal biomass in terms of carbon. Bacterial concentration was converted to biomass by the conversion factor of $12 \mathrm{fg} \mathrm{C}$ cell $^{-1}$ (Simon \& Azam 1989). Chlorophyll concentration was converted to algal biomass by applying the conversion factor $1 \mathrm{~g} \mathrm{chl} \mathrm{a}=50 \mathrm{~g} \mathrm{C}$, which is the mean value of the measurements of Antia et al. (1963).

The ratio APA:AMA was calculated by dividing alkaline phosphatase by aminopeptidase activity.

\section{RESULTS}

Initial conditions of the water used for each experiment are shown in Table 1.

Initial nutrient concentrations in long-term experiments were lower in the continuous-enrichment than in the single-pulse experiments. The single-pulse experiment started with the highest density of microorganisms.

Specific activities, both APA and AMA, were higher in the continuous-enrichment than in the long-term single-pulse experiments. The APA:AMA ratio was about 3 to 6 times lower in the short-term than in the long-term experiments.

\section{Long-term continuous-enrichment experiment}

Nutrients, chl $a$ and bacterial concentrations, as well as ectoenzyme activities in the long-term continuous- 
Table 1. Initial conditions of the water used for the experiments. bd: below detection; nd: not determined

\begin{tabular}{|c|c|c|c|}
\hline Initial values & $\begin{array}{l}\text { Long-term } \\
\text { continuous }\end{array}$ & $\begin{array}{l}\text { Long-term } \\
\text { single-pulse }\end{array}$ & $\begin{array}{l}\text { Short-term } \\
\text { single-pulse }\end{array}$ \\
\hline TIN $(\mu \mathrm{M})$ & bd & 0.97 & nd \\
\hline Phosphate $(\mu \mathrm{M})$ & 0.02 & 0.05 & nd \\
\hline $\mathrm{N}: \mathrm{P}$ ratio & ? & 19.4 & nd \\
\hline Chlorophyll a ( $\left.\mu \mathrm{g} \mathrm{l}^{-1}\right)$ & 0.32 & 0.90 & nd \\
\hline Bacterial conc. $\left(\right.$ cells ml ${ }^{-1}$ ) & $1.13 \times 10^{6}$ & $1.78 \times 10^{6}$ & $4.79-7.85 \times 10^{5}$ \\
\hline Bacterial production (pmol leucine $\mathrm{l}^{-1} \mathrm{~h}^{-1}$ ) & nd & 164 & nd \\
\hline Specific APA $\left(\mu \mathrm{mol} \mu \mathrm{g} \mathrm{C}^{-1} \mathrm{~h}^{-1}\right)$ & 3.16 & 1.05 & nd \\
\hline Specific AMA ( $\left.\mu \mathrm{mol} \mu \mathrm{g} \mathrm{C}^{-1} \mathrm{~h}^{-1}\right)$ & 1.66 & 0.70 & nd \\
\hline APA:AMA & 1.90 & 1.79 & $0.22-0.59$ \\
\hline
\end{tabular}

enrichment experiment are shown in Fig. 1. A bloom of phytoplankton was formed only in the np treatment, with maximum chl a concentrations (3.18 $\mu \mathrm{g} \mathrm{l}^{-1}$ ) reached on Day 3. Bacteria in $\mathrm{np}$ achieved their maximum concentration on Day $2\left(3.22 \times 10^{6}\right.$ cell ml $\left.{ }^{-1}\right)$ and stayed at this level for the rest of the experiment. Specific APA, as APA per total carbon content of bacteria and phytoplankton, showed clearly higher values in the treatments with no phosphorus addition (up to $11 \mu \mathrm{mol} \mu \mathrm{g} \mathrm{C}^{-1} \mathrm{~h}^{-1}$ ) than in the treatment were $\mathrm{P}$ was added. In spite of inorganic phosphorus additions, $\mathrm{P}$ concentration in the $\mathrm{np}$ treatment was always below $0.1 \mu \mathrm{M}$. Total nitrogen concentration in k controls was low (below $0.53 \mu \mathrm{M}$ ) during the experiment. Nitrogen in the $\mathrm{n}$ treatments increased steadily due to the daily additions, reaching a maximum concentration of $4.4 \mu \mathrm{M}$ on the last day. In the np treatments, however, nitrogen concentrations increased only slightly and then leveled off, with values between 0.68 and $1.16 \mu \mathrm{M}$. Specific AMA did not show a clear pattern throughout the experiment, ranging from 1 to $3 \mu \mathrm{mol} \mu \mathrm{g} \mathrm{C}^{-1} \mathrm{~h}^{-1}$.

The N:P ratio was clearly higher in the P-deficient (n) than in the other treatments during the experiment (between 24 and 89). The APA:AMA ratio was clearly lower in the $\mathrm{np}$ treatment than in the $\mathrm{k}$ and $\mathrm{n}$ treatments. The $\mathrm{n}$ treatment exhibited ratios twice as high as those in the np treatment throughout the experiment, with a maximum of 4.55 .

\section{Long-term single-pulse experiment}

The results of the single-pulse enrichment experiment are shown in Fig. 2, and replicates are plotted separately in order to evaluate the effect of an extra P addition after Day 7 in one of the $n$ and $n p$ replicates. As in the continuous-pulse experiment, the addition that clearly stimulated algal growth was $\mathrm{np}$, and a peak was detected on Day 4 in both replicates (18 and

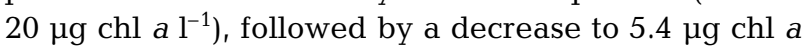
$\mathrm{I}^{-1}$ on Day 7. $\mathrm{N}$ additions caused a slow increase in

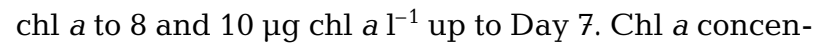
trations stayed low in the controls $\left(0.16\right.$ and $\left.1.42 \mu \mathrm{g} \mathrm{l}^{-1}\right)$.

Bacterial concentration initially increased in all treatments during the first $2 \mathrm{~d}$ of incubation and then decreased to a minimum on Day 5. In the np treatments, the collapse of the phytoplankton bloom up to Day 6 was followed by a steady increase in bacterial abundance, which reached 2.2 and $2.8 \times 10^{6}$ cells ml $^{-1}$ on Day 7 . In both the $\mathrm{k}$ and the $\mathrm{n}$ treatments, bacterial numbers showed a continuous decrease towards the end of the experiment. Bacterial production showed an initial peak in the $\mathrm{n}$ and $\mathrm{np}$ treatments of about 500 pmol leucine (leu) $\mathrm{l}^{-1} \mathrm{~h}^{-1}$ on Days 1 and 2. Production then decreased and remained low in the $n$ treatment, and increased to 1262 and 1527 pmol leu $\mathrm{l}^{-1} \mathrm{~h}^{-1}$ in the np treatment.

Nutrient concentrations were always low in the controls, below $0.16 \mu \mathrm{M} \mathrm{N}$ and $0.12 \mu \mathrm{M}$ P. Initial N concentrations in the $\mathrm{n}$ and $\mathrm{np}$ treatments were ca $20 \mu \mathrm{M}$, and decreased continuously. The decrease in $\mathrm{N}$ was more marked in the np treatments, declining to less than $0.2 \mu \mathrm{M}$. The $\mathrm{n}$ treatments showed P levels similar to those in the $\mathrm{k}$ treatment during the experiment (below 0.11). In the np treatments, $\mathrm{P}$ decreased slowly from an initial $1.1 \mu \mathrm{M}$ to almost undetectable concentrations on Day 5.

The APA:AMA ratio was clearly highest in the n treatments from Day 4 onwards. In the $\mathrm{k}$ treatments, values were between 1 and 2, and in the np treatments always below 1, suggesting that the consumption of both nutrients occurred at a similar rate and deficiency gradually increased simultaneously for both nutrients.

The highest specific APA was also found in $\mathrm{k}(8.5 \mu \mathrm{mol}$ $\mu \mathrm{g} \mathrm{C}^{-1} \mathrm{~h}^{-1}$ at Day 7), and was the lowest in the $\mathrm{np}$ treatments, which had a $\mathrm{P}$ addition.

\section{Response to additional phosphorus pulse}

In the long-term single-pulse experiment, a high concentration of $\mathrm{P}$ was added to 1 replicate of the $\mathrm{n}$ and $\mathrm{np}$ 
[n (a) and np (a)] treatments on Day 7 (Fig. 2). Addition of $\mathrm{P}$ to the $\mathrm{np}$ (a) container did not seem to have any clear effect, since no differences in chl $a$ and bacterial numbers were found between $n p(a)$ and $n p(b)$. TIN concentration was close to the detection limit, and $\mathrm{P}$ in $\mathrm{np}(\mathrm{a})$ increased to almost $1 \mu \mathrm{M}$ due to the addition, followed by a slight decrease to 0.8 after $30 \mathrm{~h}$. Bacterial production showed a similar pattern in both treatments $\mathrm{np}(\mathrm{a})$ and $\mathrm{np}(\mathrm{b})$. The ratio APA:AMA remained low $(\leq 0.5)$ after the $P$ pulse. No changes in either specific AMA or APA were observed in any np treatment.

In the $\mathrm{n}$ treatments, however, the replicate with additional $\mathrm{P}$ pulse (a) did deviate from the replicate with no such addition. Chlorophyll a increased slightly (to $10.8 \mu \mathrm{g}$ $\mathrm{l}^{-1}$ ) in the $\mathrm{n}(\mathrm{a})$ container, while in $\mathrm{n}(\mathrm{b})$ no changes were detected. The increase in bacterial numbers in $\mathrm{n}$ (a) was 5 -fold compared to $\mathrm{n}$ (b) $30 \mathrm{~h}$ after the addition. Bacterial production reflected this increase in bacterial concentrations in the $\mathrm{n}$ (a) container by a 10 -fold increase compared to $\mathrm{n}(\mathrm{b})$. $\mathrm{N}$ concentration in the $\mathrm{n}$ (a) decreased more rapidly than in $n(b)$, probably due to a higher utilization of nitrogen in response to the addition of the deficient nutrient (phosphate). The added phosphate $(1 \mu \mathrm{M})$ decreased steadily to a final concentration of $0.4 \mu \mathrm{M}$.

\section{Short-term and long-term experiments}

The results of 5 short-term experiments (4 treatments) are summarized in Fig. 3. They are represented as the
Fig. 1. Parameters measured in the long-term continuous-enrichment experiment. Mean of 2 replicate microcosms per treatment. k: control without addition; $\mathrm{n}$ : $\mathrm{N}$ addition; $\mathrm{np}$ : $\mathrm{N}$ and $\mathrm{P}$ addition. Additions were daily; dashed line (addition) shows the theoretical concentration after addition of the nutrient to the microcosms. TIN: total inorganic nitrogen; error bars $=\mathrm{SE}$
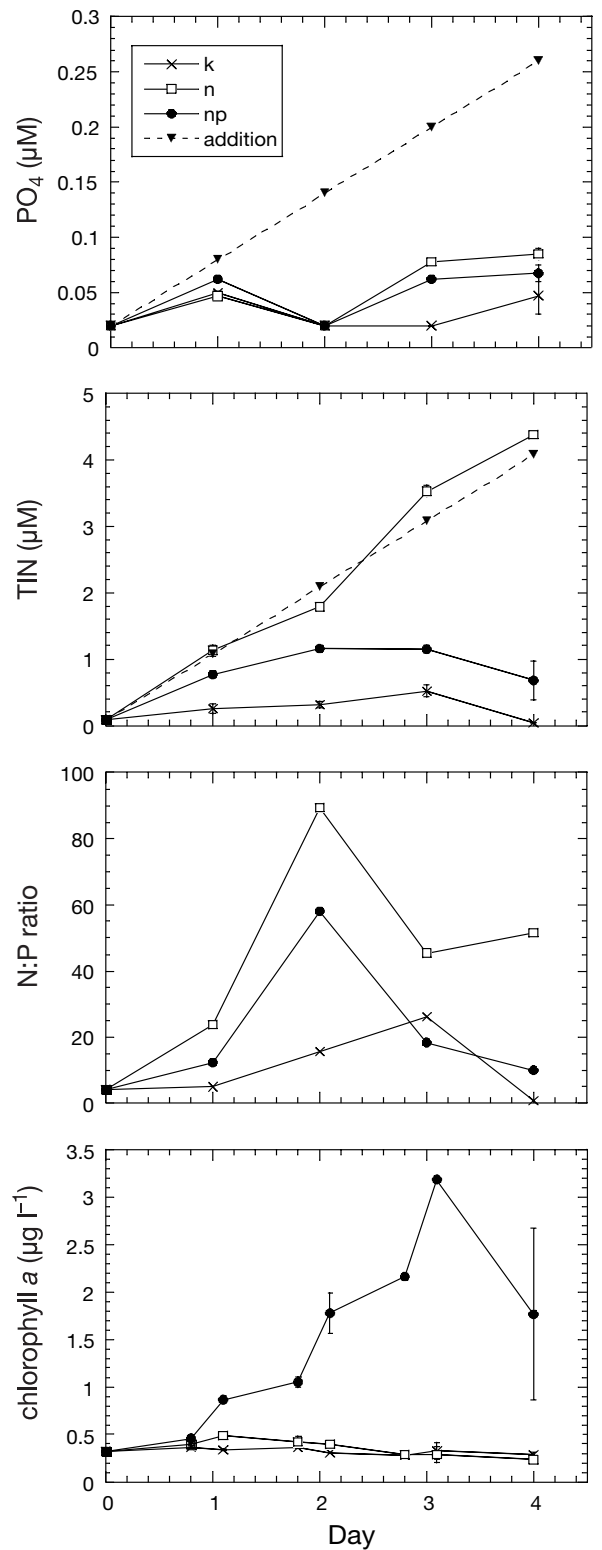
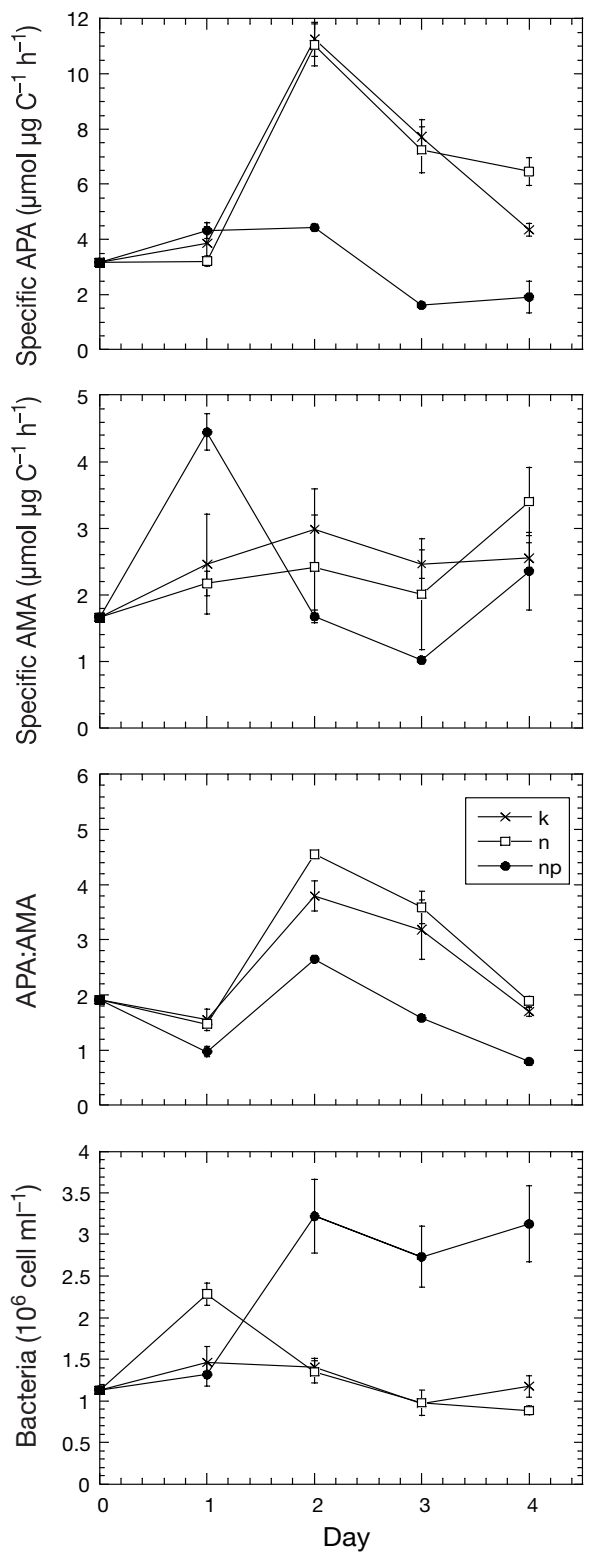
percentage of the initial APA:AMA ratio for the treatments with $\mathrm{N}, \mathrm{P}$, or $\mathrm{N}+\mathrm{P}$ addition ( $\mathrm{n}, \mathrm{p}$ and $\mathrm{np}$ ), and the control $(\mathrm{k})$. The results indicate that the addition of $\mathrm{N}$ modified the ratio only slightly compared to that without $\mathrm{N}$ addition. $\mathrm{P}$ addition, however, caused a clear de-
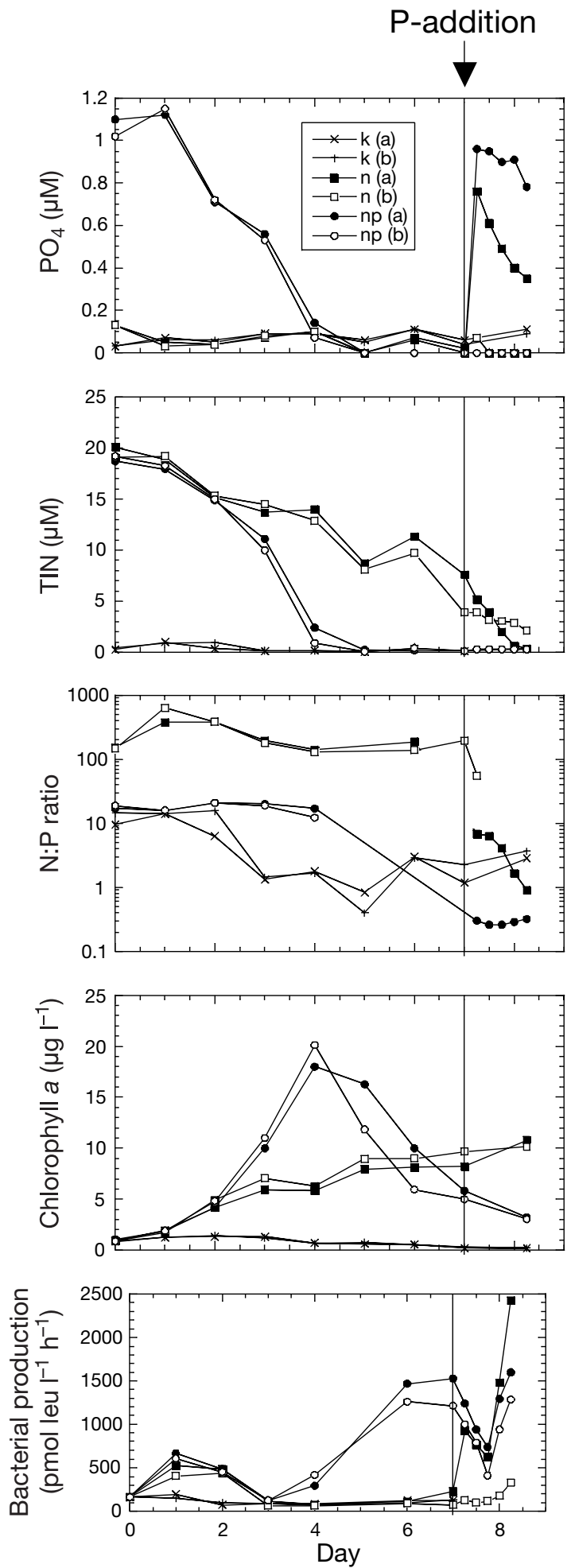

crease in the APA:AMA ratio, which was detectable whether the addition was $\mathrm{P}$ or $\mathrm{P}+\mathrm{N}$.

A similar summary of the APA:AMA ratio was made for the long-term experiments (Fig. 4a,b) using the pooled data of both experiments. In the long-term
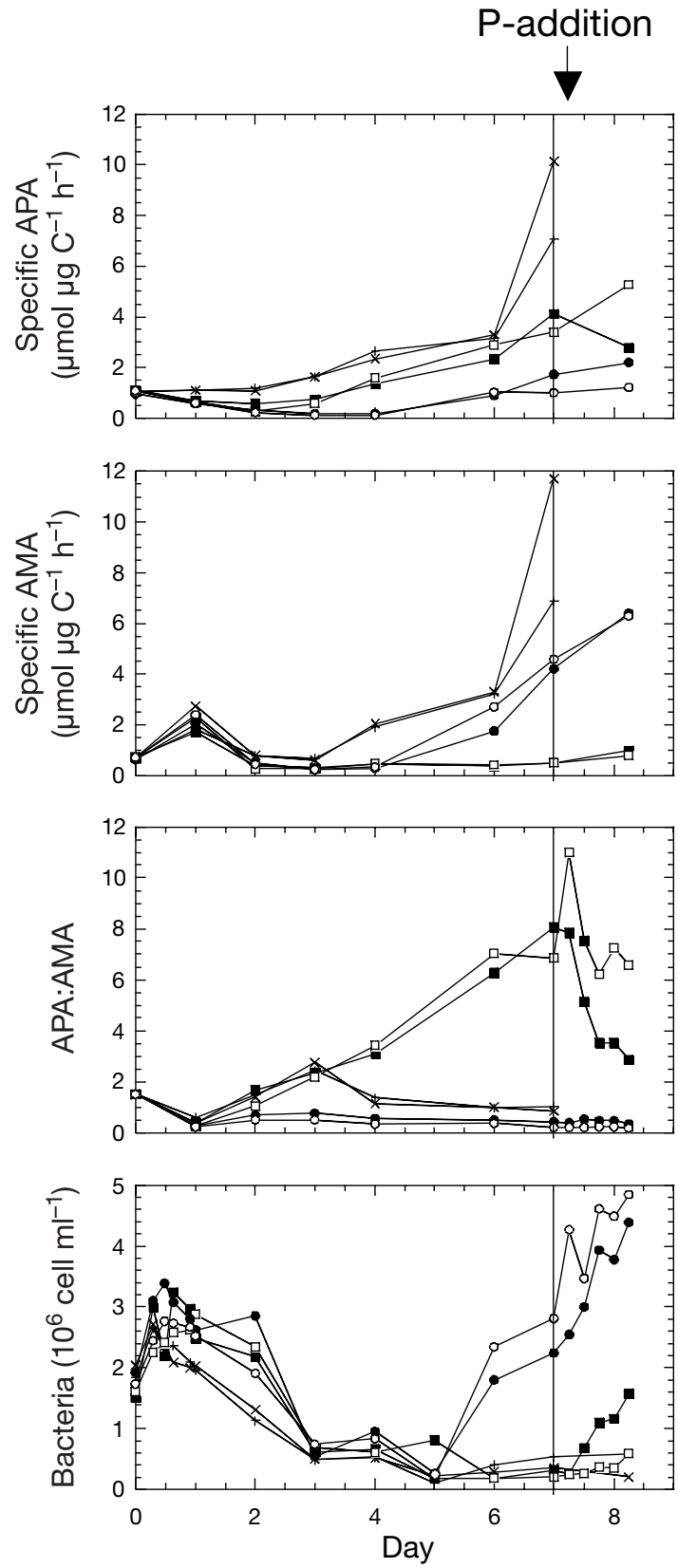

Fig. 2. Parameters measured in the long-term singlepulse experiment. Replicates ( $a$ and b) are plotted separately. k: control, without addition; $\mathrm{n}$ : nitrogen addition; $\mathrm{np}: \mathrm{N}$ and $\mathrm{P}$ addition in the Redfield ratio. Additions were made as single pulses at the beginning of the experiments; vertical line indicates an extra phosphorus pulse which was added to replicates $n(a)$ and $n p(a)$ 


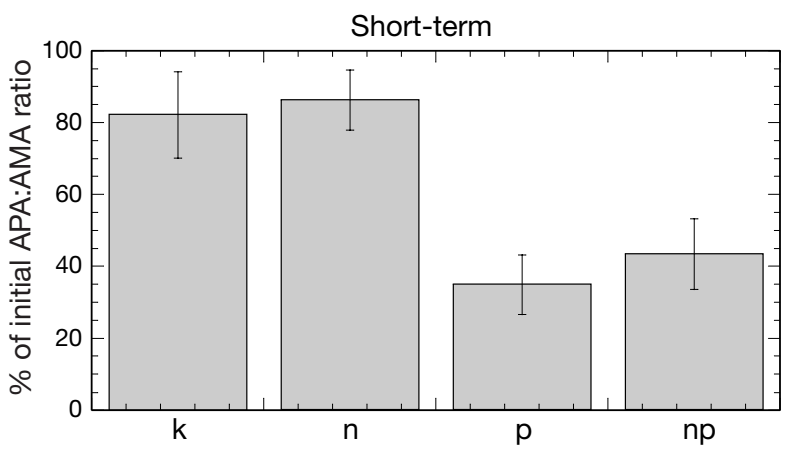

Fig. 3. Mean percent changes in APA:AMA ratios with respect to the initial ratio before nutrient additions during 5 short-term experiments (4 treatments: $k$, control without addition; $\mathrm{n}$ : $\mathrm{N}$ addition; $\mathrm{p}$ : $\mathrm{P}$ addition; $\mathrm{np}: \mathrm{N}+\mathrm{P}$ addition). Changes were calculated after $1 \mathrm{~d}$ incubation for each experiment. Error bars $=\mathrm{SE}$ of the 5 experiments

continuous-enrichment experiment we used data from Days 1 to 4 , and in the single-pulse experiment data from Days 1 to 7 . We calculated the percentage of increase in the ratio measured each day from the initial ratio, i.e. the ratio at $t_{0}$. The results showed a clear decrease in the APA:AMA ratio when $\mathrm{P}$ was added due to repression of APA activity. Addition of $\mathrm{N}$ did not have a consistent effect on the APA:AMA ratio. In the continuous-enrichment experiment, no clear difference from the control could be seen, while in the single-pulse experiment a 3-fold increase was detected. From these responses, we interpret $\mathrm{P}$ to have been always limiting, while the degree of initial $\mathrm{N}$ limitation was more variable among the different experiments.

\section{DISCUSSION}

Extracellular enzyme activity is the initial response of a microbial community to environmental changes (Karner \& Rassoulzadegan 1995) and our results indicate that ectoenzymes can indeed be appropriate physiological indicators of the nutritional status of a biological system. We believe that the APA:AMA ratio is a good example of this general principle and can be used successfully to assess N:P nutrient imbalance in aquatic communities.

In oligotrophic environments, $\mathrm{N}$ and $\mathrm{P}$ concentrations are often not measurable with standard methods. Further, in many cases more than 1 nutrient is below detection limits. Besides conceptual problems, this clearly presents a technical challenge in the study of nutrient limitation. A direct methodology indicating the degree of nutrient limitation of in situ microplanktonic populations through assessment of the cells' physiological condition would be a concrete asset. A

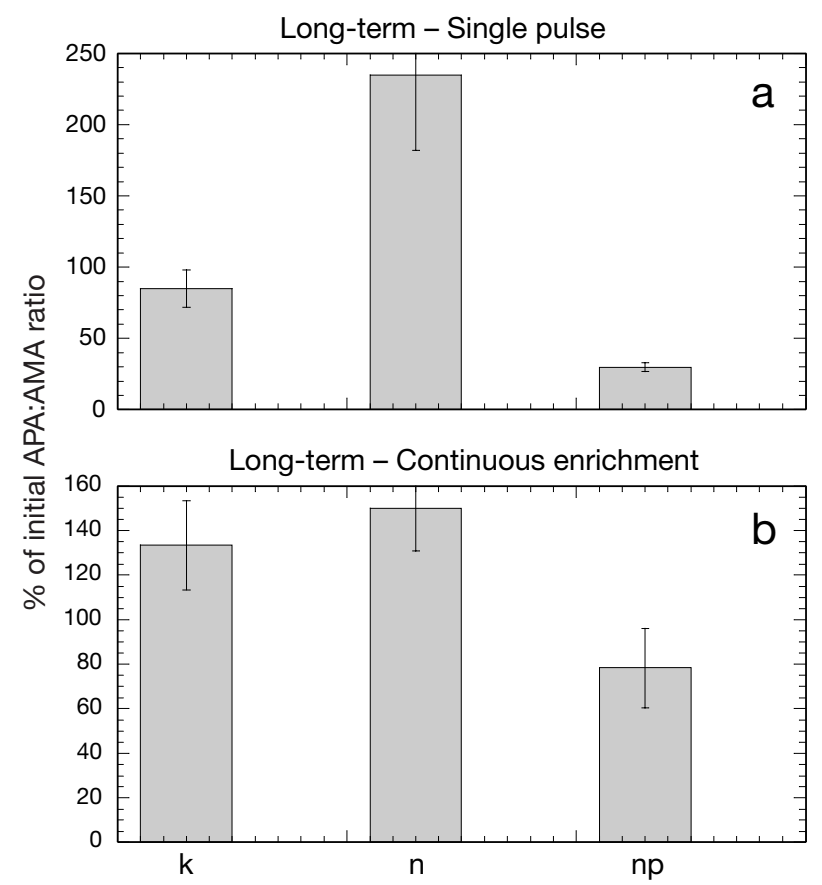

Fig. 4. Mean percent changes in APA:AMA ratios with respect to the initial ratio before nutrient additions in the long-term experiments. Changes were calculated throughout whole experiments: $7 \mathrm{~d}$ for the (a) single-pulse experiment, $4 \mathrm{~d}$ for the (b) continuous-enrichment experiment. k: control without addition; $\mathrm{n}$ : $\mathrm{N}$ addition; $\mathrm{p}$ : $\mathrm{P}$ addition; $\mathrm{np}$ : addition of both $\mathrm{N}$ and $\mathrm{P}$. Error bars = SE of the daily measurements

large number of studies using different methodologies for the evaluation of nutrient limitations have been published. Biochemical studies generally include determinations of the elemental, macromolecular and pigment composition such as the protein:DNA index (Berdalet et al. 1996). However, current biochemical composition reflects the physiological history of a cell and therefore may not reflect current deficiency, i.e. the cells nutritional status (Istvánovics et al. 1992). Estimation of the physiological processes within the microbial populations seems to be the most suitable approach for evaluating the nutritional status of cells, since these reflect a cell's immediate environment. The most studied physiological processes are photosynthesis, carbon and nitrogen metabolism, and nutrient uptake and ectoenzyme activities. The most direct methodologies target nutrient turnover times, generally those of orthophosphate (Lean \& Pick 1981, Thingstad et al. 1998) or, in the case of algae, the P-deficiency index (Istvánovics et al. 1992). These methodologies, however, are timeconsuming and use radiolabelled substrates.

Other approaches are bioassays, which consist of measuring the response to an addition of the deficient nutrient as an increase in bacterial numbers or production (Schweitzer \& Simon 1995, Thingstad et al. 1998), 
or algal growth (Bonin et al. 1989). This usuallly requires long incubations in which the community might change and be altered by the enclosure.

The use of the APA:AMA ratio to assess nutrient limitation is a novel approach. Individually, however, both APA and AMA activities have been previously used as physiological indicators, especially APA in algae. Gage \& Gorham (1985), studying Minnesota lakes, found that APA was inversely related to cellular phosphorus in the particulate organic matter. APA was significantly enhanced in phosphorus-deficient phytoplankton (Vrba et al. 1995), and has been shown to be a good indicator of phosphorus deficiency in lake-water cultures (Smith \& Kalff 1981). APA is induced by phosphorus limitation in algae (Kuenzler \& Perras 1965, Healey 1975). However, other authors (Jansson et al. 1988) have recommended that APA should not be used as an indicator of phosphorus deficiency in natural plankton assemblages unless other P-deficiency indicators are included. AMA has already been used as indicator of bacterial activity (Andersen-Elvehoy \& Thingstad 1991) and of the flux of combined amino acid nitrogen (Jacobsen \& Rai 1988).

Ectoenzyme activities alone may not give an idea of the real nutritional status of the community, since they are partially constitutive and the amount of biomass of the producers can thus play an important role in the total level of activity. Therefore, activities need to be related to other parameters which can indicate the biomass of potential enzyme producers. To calculate specific enzyme activities, one must first identify the organisms which, when undergoing certain nutrient deficiency, are able to synthesize the necessary ectoenzymes. Ectoenzymes can be produced by a large number of microorganisms, such as heterotrophic nanoflagellates (Karner et al. 1994) or zooplankton (Bochdansky et al. 1995, Jamet \& Boge 1998), although their main producers are generally algae and bacteria. Several authors have investigated the relative importance of bacterial, algal and free enzymes by selective filtration and evaluation of the activity in each size fraction. Such selective filtration may include sources of error: (1) the size of the filter may not accurately separate the different functional groups; (2) filtration pressure may detach ectoenzymes from cells; and (3) some filters may retain proteins, and therefore enzymes, altering the relative contribution of each size fraction to the total activity (Karner \& Rassoulzadegan 1995). The results in the literature on the relative contribution of functional microbial groups to the total activity of an enzyme show large variability, not only between environments, but also between seasons. AMA has been generally associated with heterotrophic bacteria (Vives-Rego et al. 1985, Chróst 1991, Münster et al. 1992). However, Chróst and co-authors found the bacterial fraction to account for only up to $12 \%$ during a bloom breakdown in Lake Plußsee (northern Germany) (Chróst et al. 1989), or about 10\% in nutrient-manipulated enclosures (Chróst \& Rai 1993). Alkaline phosphatase has been reported to be produced both by algae and bacteria, although dissolved APA may contribute to a highly variable degree (Francko 1983). A large percentage of the total APA activity has been generally attributed to algae; nevertheless, this percentage may vary widely over the year (Chróst \& Overbeck 1987). Chróst \& Overbeck found that the algal fraction dominated APA production during bloom conditions, while bacteria dominated in winter. Münster et al. (1992) found about 50 to $70 \%$ of APA freely dissolved in the water column. All this uncertainty has led several authors to avoid cell counts as an estimate of biomass for the calculation of specific activity. Some have opted for normalizing APA by estimating total biomass with ATP (Healey \& Hendzel 1980), or with total particulate organic matter, POM (Healey \& Hendzel 1979, Pettersson 1980). POM, however, is not very appropriate for systems where detritus is abundant. Other studies have assumed that all activity is produced by bacteria in the case of AMA, or by algae in the case of APA, and have calculated specific activities using bacterial numbers or chl a concentration, respectively. However, such a procedure can only be valid when the production of an enzyme is almost entirely attributable to a particular group of organisms.

Our estimates of specific activities (Figs. 1 \& 2) were calculated after bacterial counts and chl a concentrations had been converted to carbon and then summed. We thus assumed that enzyme activities were produced by both algae and bacteria. The results thus obtained provide information about the limitation status for each nutrient.

The complexity and assumptions required to calculate specific activities lead us to emphasize the utility of the APA:AMA. Our data clearly showed the usefulness of the ratio as an indicator of the dominance of $\mathrm{N}$ versus $\mathrm{P}$ deficiency. In Fig. 2, for example, we found the highest specific APA in $\mathrm{k}$ (control) conditions, where both $\mathrm{N}$ and $\mathrm{P}$ where limiting, while the highest ratio APA:AMA was detected in $n$ enclosures (P-deficient treatment).

The ultimate aim of our study was to present an equation that would allow us to infer a N:P ratio from a APA:AMA ratio. However, when comparing N:P ratios with APA:AMA ratios in our microcosms, the $r^{2}$ value $(0.459, \mathrm{n}=66)$ indicates that APA:AMA does not completely reflect $\mathrm{N}: \mathrm{P}$. It is not surprising that the residual nutrient concentration does not reflect the rate-limiting step in the chain of nutrient regeneration, since production and consumption are tightly balanced. Ectoen- 
zymes are produced to solve an anticipated shortage of $\mathrm{N}$ or $\mathrm{P}$ and rectify the nutrient imbalance. Additionally, the complex origin of enzyme activities includes constitutive enzymes and various possible enzymeexpression regulation mechanisms in various microbial subgroups. Similarly, the N:P ratio of the microbial environment certainly displays wide qualitative variability that remained undetected in our experiments as in most other similar studies, even those focusing on nutrients exclusively. We can, however, show that the trends in APA:AMA ratios clearly did reflect the nutrient imbalances we experimentally induced.

Substrate induction for expression of certain microbial enzymes has been reported by Chróst (1989). It has also been demonstrated, however, that production of enzymes such as APA is likely to reflect deficiency of the hydrolysis end product (Chróst et al. 1989). Enzyme activity response to nutrient variability is rapid compared to changes in biomass and species composition, as shown in Fig. 2 for the second part of the long-term single-pulse enrichment experiment. After Day 7, the response to the extra P addition in the $\mathrm{np}$ containers differed from that in the $\mathrm{n}$ conditions. The extra $\mathrm{P}$ addition in the $\mathrm{np}$ (a) containers did not increase the APA:AMA ratios over those in the np (b) containers, to which $\mathrm{P}$ was not added. The lack of response in this ratio indicates that both $\mathrm{N}$ and $\mathrm{P}$ had already been consumed at that point of the experiment (concentration values were almost to undetectable values: Fig. 2), and therefore we can assume that both $\mathrm{N}$ and $\mathrm{P}$ were limiting. In contrast, the treatment designed to induce relative $\mathrm{P}$ deficiency, i.e., the $\mathrm{n}$ treatment, responded quickly to Day $7 \mathrm{P}$ addition. After only $6 \mathrm{~h}$, the APA:AMA ratio showed clear divergences, decreasing in $\mathrm{n}$ (a) containers to which $\mathrm{P}$ had been added, and displaying higher values in $\mathrm{n}(\mathrm{b})$ containers (without $\mathrm{P}$ addition) (Fig. 2). It seems that the first responders to the new nutrient condition were bacteria. Increases in bacterial numbers were evident as early as $6 \mathrm{~h}$, increasing about 20 -fold over the $24 \mathrm{~h}$ following the $\mathrm{P}$ pulse in this experiment. Conversely, chl a concentrations only increased 1.5-fold (Fig. 2). The bacterial response was also reflected in the 10-fold increase in bacterial production after $\mathrm{P}$ addition. Incidentally, excess $\mathrm{N}$ was consumed as rapidly as newly added $\mathrm{P}$, indicating the dominance of $\mathrm{P}$ limitation over $\mathrm{N}$ limitation (Fig. 2). We believe that in the long-term experiments there must have been a change in bacterial and algal species. This change, however, must have been concomitant with changes in the nutrient concentration, and therefore, enzyme activities, as shown by Pinhassi et al. (1999).

Our results have shown that the ratio between the ectoenzyme activities alkaline phosphatase and aminopeptidase (APA:AMA) clearly reflects experimentally induced nutrient imbalances. We believe that this approach is easy, quick, and provides insight into nutrient deficiency in the whole microbial ecosystem. The proposed ratio would be useful for monitoring short-term changes or fluctuations in nutrient availability. However, further research is needed to extend the application of this ratio to different systems.

Acknowledgements. We would like to thank to 3 anonymous reviewers and Francesc Peters, Rafel Simó, Mercedes Castaño and Josep M. Gasol for their help. This work was supported by the European projects MEDEA (MAS3-CT950016), and BIOHAB (EVK3-CT99-00015), and the Spanish project SERET (MAR98-0854), and MAST II, as well as by a contract from the Spanish Ministry of Education to M.M.S.

\section{LITERACURE CITED}

Andersen-Elvehoy IL, Thingstad T (1991) Detection of limiting factors for bacterial activity using protease activity. Kiel Meeresforsch Sonderh 8:392-398

Antia NJ, McAllister CD, Parsons TR, Stephens K, Strickland JDH (1963) Further measurements of primary production using a large-volume plastic sphere. Limnol Oceanogr 8: 166-183

Berdalet E, Marrasé C, Estrada M, Arin L, MacLean ML (1996) Microbial community responses to nitrogen- and phosphorus-deficient nutrient inputs: microplankton dynamics and biochemical characterization. J Plankton Res 18(9):1627-1641

Berges JA, Falkowski PG (1996) Cell-associated proteolytic enzymes from marine phytoplankton. J Phycol 32:566-574

Berland BR, Bonin DJ, Maestrini SY (1980) Azote ou phosphore? Considérations sur le 'paradoxe nutritionnel' de la mer Méditerranée. Oceanol Acta 3:135-142

Bochdansky A, Puskaric S, Herndl GJ (1995) Influence of zooplankton grazing on free dissolved enzymes in the sea. Mar Ecol Prog Ser 121:53-63

Bonin DJ, Bonin MC, Berman T (1989) Mise en évidence expérimentale des facteurs nutritifs limitants de la production du micro-nanoplancton et de l'ultraplancton dans une eau côtière de la Méditerranée orientale (Haïfa, Israël). Aquat Sci 51:129-152

Chróst RJ (1989) Characterization and significance of $\beta$-glucosidase activity in lake water. Limnol Oceanogr 34: 660-672

Chróst RJ (ed) (1991) Microbial enzymes in aquatic environments. Springer-Verlag, Berlin

Chróst RJ, Overbeck J (1987) Kinetics of alkaline phosphatase activity and phosphorus availability for phytoplankton and bacterioplankton in Lake Plußsee (North German eutrophic lake). Microb Ecol 13:229-248

Chróst RJ, Rai H (1993) Ectoenzyme activity and bacterial secondary production in nutrient-impoverished and nutrientenriched freshwater mesocosms. Microb Ecol 25:131-150

Chróst RJ, Münster U, Rai H, Albrecht D, Witzel K, Overbeck J (1989) Photosynthetic production and exoenzymatic degradation of organic matter in the euphotic zone of a eutrophic lake. J Plankton Res 11:223-242

Coffin RB (1989) Bacterial uptake of dissolved free and combined amino acids in estuarine waters. Limnol Oceanogr 34:531-542

Cotner JB, Ammerman JW, Peele ER, Bentzen E (1997) Phos- 
phorus-limited bacterioplankton growth in the Sargasso Sea. Aquat Microb Ecol 13:141-149

Downing JA (1997) Marine nitrogen:phosphorus stoichiometry and the global N:P cycle. Biogeochemistry 37:237-252

Francko DA (1983) Size-fractionation of alkaline-phosphatase activity in lake water by membrane filtration. J Freshw Ecol 2:305-309

Gage MA, Gorham E (1985) Alkaline phosphatase activity and cellular phosphorus as an index of the phosphorus status of phytoplankton in Minnesota lakes. Freshw Biol 15:227-233

Gasol JM, del Giorgio PA (2000) Using flow cytometry for counting natural planktonic bacteria and understanding the structure of planktonic bacterial communities. Sci Mar 64(2):197-224

Grasshoff K, Ehrhardt M, Kremling K (1983) Methods on seawater analysis, 2nd edn. Verlag Chemie, Weinheim

Guildford SJ, Hecky RE (2000) Total nitrogen, total phosphorus, and nutrient limitation in lakes and oceans: is there a common relationship? Limnol Oceanogr 45:1213-1223

Guillard RRL (1975) Culture of phytoplankton for feeding marine invertebrates. In: Smith W, Chanley $\mathrm{MH}$ (eds) Culture of marine invertebrates. Plenum Publishing Corporation, New York, p 26-60

Healey FP (1975) Physiological indicators of nutrient deficiency in algae. Fish Mar Serv Tech Rep 585:30 p

Healey FP, Hendzel LL (1976) Physiological changes during the course of blooms of Aphanizomenon flos-aquae. J Fish Res Board Can 33:36-41

Healey FP, Hendzel LL (1979) Fluorimetric measurement of alkaline phosphatase activity in algae. Freshw Biol 9: 429-439

Healey FP, Hendzel LL (1980) Physiological indicators of nutrient deficiency in lake phytoplankton. Can J Fish Aquat Sci 37:442-453

Henrichs SM, Farrington JW, Lee C (1984) Peru upwelling region sediments near $15^{\circ} \mathrm{S}$. 2. Dissolved free and total hydrolyzable amino acids. Limnol Oceanogr 29:20-34

Hoober JK, Hughes MJ (1992) Purification and characterization of a membrane-bound protease from Chlamydomonas reinhardtii. Plant Physiol 99:932-937

Hoppe HG (1983) Significance of exoenzymatic activities in the ecology of brackish water: measurements by means of methylumbelliferyl-substrates. Mar Ecol Prog Ser 11: 299-308

Hoppe HG (1993) Use of fluorogenic model substrates for extracellular enzyme activity (EEA) measurement of bacteria. In: Kemp PF, Sherr BF, Sherr EB, Cole JJ (eds) Handbook of methods in aquatic microbial ecology. Lewis Publishers, Boca Raton, FL, p 423-431

Hoppe HG, Kim SJ, Gocke K (1988) Microbial decomposition in aquatic environments: combined process of extracellular enzyme activity and substrate uptake. Appl Environ Microbiol 54:784-790

Istvánovics V, Pettersson K, Pierson D, Bell R (1992) Evaluation of phosphorus deficiency indicators for summer phytoplankton in Lake Erken. Limnol Oceanogr 37:890-900

Jacobsen TR, Rai H (1988) Determination of aminopeptidase activity in lakewater by a short-term kinetic assay and its application in two lakes of differing eutrophication. Arch Hydrobiol 113:359-370

Jamet D, Boge G (1998) Characterisation of marine zooplankton alkaline phosphatase activity in relation to water quality. Hydrobiologia 374:311-316

Jansson M, Olsson H, Pettersson K (1988) Phosphatases: origins, characteristics and function in central Sweden. Hydrobiologia 101:57-175
Karner M, Rassoulzadegan F (1995) Extracellular enzyme activity: indications for high short-term variability in a coastal marine ecosystem. Microb Ecol 30:143-156

Karner M, Ferrier-Pages C, Rassoulzadegan F (1994) Phagotrophic nanoflagellates contribute to occurrence of alphaglucosidase and aminopeptidase in marine environments. Mar Ecol Prog Ser 114:237-244

Keil RG, Kirchman DL (1991) Dissolved combined amino acids in marine waters as determined by a vapor-phase hydrolysis method. Mar Chem 33:243-259

Kirchman DL (1993) Leucine incorporation as a measure of biomass production by heterotrophic bacteria. In: Kemp PF, Sherr BF, Sherr EB, Cole JJ (eds) Handbook of methods in aquatic microbial ecology. Lewis Publishers, Boca Raton, FL, p 509-512

Kirchman DL, K'nees E, Hodson R (1985) Leucine incorporation and its potential as a measure of protein synthesis by bacteria in natural aquatic systems. Appl Environ Microbiol 49:599-607

Krom MD, Kress N, Brenner S, Gordon LI (1991) Phosphorus limitation of primary productivity in the eastern Mediterranean Sea. Limnol Oceanogr 36:424-432

Kuenzler EJ, Perras IP (1965) Phosphatases of marine algae. Biol Bull (Woods Hole) 128:271-284

Lean DRS, Pick FR (1981) Photosynthetic response of lake plankton to nutrient enrichment: a test for nutrient limitation. Limnol Oceanogr 26:1001-1019

Martinez J, Azam F (1993) Aminopeptidase activity in marine chrooccoid cyanonobacteria. Appl Environ Microb 59: 3701-3707

Münster U, Nurminen J, Einiö P, Overbeck J (1992) Extracellular enzymes in a small polyhumic lake: origin, distribution and activities. Hydrobiologia 243/244:47-59

Patel AB, Fukami K, Nishijima T (2000) Regulation of seasonal variability of aminopeptidase activities in surface and bottom waters on Uranouchi Inlet, Japan. Aquat Microb Ecol 21:139-149

Peters F, Redondo JM (1997) Turbulence generation and measurement: application to studies on plankton. Sci Mar 61 (Suppl 1):205-228

Pettersson K (1980) Alkaline phosphatase activity and algal surplus phosphorus as phosphorus-deficiency indicators in Lake Erken. Arch Hydrobiol 89:54-87

Pinhassi J, Azam F, Hemphälä J, Long RA, Martinez J, Zweifel UL, Hagström Ä (1999) Coupling between bacterioplancton species composition, population dynamics, and organic matter degradation. Aquat Microb Ecol 17: 13-26

Porter K, Feig YS (1980) The use of DAPI for identifying and counting aquatic microflora. Limnol Oceanogr 25:943-948

Rose C, Axler RP (1998) Uses of alkaline phosphatase activity in evaluating phytoplankton community phosphorus deficiency. Hydrobiologia 361:145-156

Sala MM, Güde H (1996) Influence of algae and crustacean zooplankton on patterns of microbial hydrolytic enzyme activities - an experimental approach. Arch Hydrobiol Spec Iss (Adv Limnol) 48:143-154

Sala MM, Güde H (1998) Role of protozoans on the microbial ectoenzymatic activity during the degradation of macrophytes. Aquat Microb Ecol 20:75-82

Schweitzer B, Simon M (1995) Growth limitation of planktonic bacteria in a large mesotrophic lake. Microb Ecol 30:89-104

Simon M, Azam F (1989) Protein content and protein synthesis rates of planktonic marine bacteria. Mar Ecol Prog Ser 51:201-213

Smith DC, Azam F (1992) A simple, economical method for measuring bacterial protein synthesis rates in seawater 
using ${ }^{3} \mathrm{H}$-leucine. Mar Microb Food Webs 6:107-114

Smith REH, Kalff J (1981) The effect of phosphorus limitation on algal growth rates: evidence from alkaline phosphatase. Can J Fish Aquat Sci 38:1421-1427

Thingstad TF, Zweifel UL, Rassoulzadegan F (1998) P limitation of heterotrophic bacteria and phytoplankton in the northwest Mediterranean. Limnol Oceanogr 43:88-94

Tyrrell T (1999) The relative influences of nitrogen and phosphorus on oceanic primary production. Nature 400:525-531

Tyrrell T, Law CS (1997) Low nitrate: phosphate ratios in the global ocean. Nature 387:793-796

Vives-Rego J, Billen G, Fontigny A, Somville M (1985) Free and attached proteolytic activity in water environments.

Editorial responsibility: Frede Thingstad,

Bergen, Norway
Mar Ecol Prog Ser 21:245-249

Vrba J, Vyhnálek V, Hejzlar J, Nedoma J (1995) Comparison of phosphorus deficiency indices during a spring phytoplankton bloom in a eutrophic reservoir. Freshw Biol 33:73-81

Wu J, Sunda W, Boyle EA, Karl DM (2000) Phosphate depletion in the Western North Atlantic Ocean. Science 289: 759-762

Yentsch CS, Menzel DW (1963) A method for the determination of phytoplankton chlorophyll and phaeophytin by fluorescence. Deep-Sea Res 10:221-231

Zohary T, Robarts RD (1998) Experimental study of microbial $\mathrm{P}$ limitation in the eastern Mediterranean. Limnol Oceanogr 43:387-395

Submitted: May 29, 2000; Accepted: November 20, 2000 Proofs received from author(s): January 29, 2001 